Bangl. J. Vet. Med. (2010). 8(1): 27 - 33

\title{
EPIDEMIOLOGY OF ECTOPARASITIC INFESTATIONS IN CATTLE AT BHAWAL FOREST AREA, GAZIPUR
}

\author{
S. A. Rony ${ }^{1}$, M. M. H. Mondal ${ }^{1}$, N. Begum ${ }^{1}$, M. A. Islam ${ }^{2}$ and S. Affroze ${ }^{1}$ \\ ${ }^{1}$ Department of Parasitology, ${ }^{2}$ Department of Medicine, Faculty of Veterinary Science, Bangladesh Agricultural \\ University, Mymensingh-2202, Bangladesh.
}

\begin{abstract}
To determine the prevalence of ectoparasitic infestation of cattle in and around the Bhawal forest area in Gazipur district in Bangladesh, an epidemiological investigation was carried out during the period from November 2008 to October 2009. Of 206 cattle examined, $132(64.07 \%)$ were found to be infested with several species of ticks and lice. The prevalence rate was highest in case of Boophilus microplus (45.63\%) followed by Rhipicephalus sanguineus (36.89\%), Linognathus vituli ((23.30\%), Haematopinus euysternus (17.96\%), Hemaphysalis bispinosa (16.50\%), and Damalinia bovis (8.25\%). Results revealed that, older cattle aged $>8$ years are more $(71.11 \%)$ susceptible than that of adults aged $>2-8$ years $(67.74 \%)$, and young aged $\leq 2$ years $(47.05 \%)$. In females, prevalence of ectoparasitic infestation was observed significantly $(p<0.005)$ higher than that of male. Prevalence of ectoparasitic infestation was significantly $(p<0.005)$ higher in animal reared under free range system than that of semi-intensive system and cattle with malnourished and poor health status were found to be significantly more vulnerable to such parasitic infestation than normal healthy cattle. Seasonal prevalence showed that, significantly $(p<0.001)$ higher prevalence occurred in summer season $(78.46 \%)$, followed by winter $(62.85 \%)$ and rainy season (52.11\%). Mean parasitic burden were $1.49 \pm 0.80$ per square inches of heavily infected area.
\end{abstract}

Key words: Epidemiology, ecto-parasite, cattle, Bhawal forest, prevalence

\section{INTRODUCTION}

Tropical, agro-based Bangladesh has 47.51 million livestock of which 22.87 million are cattle (BBS, 2008). Livestock, the backbone of Bangladesh's agricultural economy, is at risk of decline in production due to number of ecto- and endo-parasites. Bangladesh is usually hot and humid except in winter and the climatic condition of Bangladesh is very conducive to a wide variety of parasites as well as ticks (Razzak and Shaikh, 1969). Ectoparasitic infestation is one of the major veterinary problems affecting livestock industries in many parts of the world (Hourrigan, 1979). Ectoparasites including lice, ticks, mites etc. play an important role in the transmission of certain pathogens (Loomis, 1986). The ectoparasites are known to cause heavy economic losses to livestock industry due to their usual habit of blood sucking, which adversely affects the economic production (Branscheid and Schroer, 1997). Among ecto-parasites, ticks have been recognized as the notorious threat due to severe irritation, allergy and toxicosis (Niyonzema \& Kiltz, 1986). In some cases, ticks have been reported to cause lowered productivity, mortality (Niyonzema and Kiltz, 1986) and transmit such diseases as babesiosis, theileriosis, anaplasmosis etc (Norval et. al., 1984). Ticks act not only as potential vectors but also as reservoirs of certain infectious agents e.g. Pasteurella multocida, Brucella abortus and Salmonella typhimurium in man and animals (Jongejan and Uilenberg, 2004).

Besides ticks lice also cause harm in cattle health. Lice infested animals keep poor physical condition and develop an unthrifty, anemic appearance and discoloured greasy hair (Nelson, 1984). Louse free animals have been reported to be more profitable than infested animals due to increased rate of weight gain and more feed utilization (Kettle, 1974). In addition, lice infestation contributes to huge economic losses due to damage to skin and hide in the form of light flecks and spots followed by secondary bacterial infection or scratching behaviour and inflammation of the skin (Nafstad and Gronstol, 2001b). The situation of ticks and tick-borne diseases in animals have been partially documented in Bangladesh by number of authors (Samad, 2000), but these studies are fragmented and not yet done in Bhawal forest area.

\footnotetext{
*Corresponding author: e-mail: amin1419@yahoo.com 


\section{S. A. Rony and others}

Bhawal Sal forest of Gazipur is tropical moist deciduous type of forest which actually presents in lowland and flood plain based area. Besides, this forest contains a huge variety of floral composition. Moreover different types of mammals, reptile, aves, amphibian depends on these kinds of trees, as their habitat as well as niche (Ashraful Alam, 2008). Different studies have been conducted on various aspects of tick prevalence in various parts of the country and abroad as well but not yet done in Bhawal Forest area in Gazipur. Duly considering the limitation of information on ectoparasitic infestation of domestic animals in and around Bhawal forest area and the importance of cattle wealth in the national economy, the present study was undertaken with the aim to determine prevalence and associated risk factors of ectoparasitic infestation.

\section{MATERIALS AND METHODS}

\section{Study area and period}

The present research was conducted in cattle of Bhawal forest area in Gazipur district which is located 40km north to Dhaka city. Morphological study for identification of species of ectoparasites was conducted in the Department of Parasitology, Bangladesh Agricultural University, Mymensingh and Statistical analysis of epidemiological data were done through the Department of Agricultural Statistic, Bangladesh Agricultural University, Mymensingh. The investigation was carried out during the period from November 2008 to October 2009.

\section{Survey design and sampling}

Two steps cluster sampling was performed for this study. Ten villages from in and around Bhawal forest were selected randomly followed by ten house hold from each of the village selected, from which 1- 6 cattle were examined for ectoparasites. The investigation was carried out in three visits on three seasons (Summer: MarchJune; Rainy: July-October and Winter: November-February). Total two hundred and six (206) cattle were selected randomly from different parts in and around the Bhawal forest area in Gazipur district for the convenience of the study and availability of the cattle.

\section{Collection and preservation of samples}

The selected cattle were thoroughly investigated by close inspection, parting the hairs against their natural direction for the detection of ectoparasites. After that, a thorough epidemiological investigation was performed using a semi-structured questionnaire including the animal level variables such as age, sex, health status and rearing system. Age was determined by asking the owner and farm attendant and by visual inspection and also by dentition whenever possible. Animals were categorized based on age as young ( $\leq 2$ years), adult ( $>2$ years to 8 years), and old ( $>8$ years).

Ectoparasites were collected from the different parts of the body of the individual cattle by hand picking. When required, small hairbrush dipped in ethanol was used for the collection of ticks. The point of attachment was smeared with ethanol. Adequate precautions were taken to preserve the mouthparts and appendages of the ectoparasites during collection. Ectoparasites were preserved in $70 \%$ alcohol in clean, well-stopper glass vials which were labeled properly.

\section{Identification of ectoparasites}

Morphology of ectoparasites was studied in the laboratory with the help of dissecting (4X) and compound (10X) microscope. Ectoparasites were identified according to the keys and descriptions given by Wall \& Shearer (1997) and Soulsby (1982) by preparing permanent slides according to the procedures described by Cable (1967).

\section{Statistical analysis}

Statistical analyses were carried out by using Statistical Package for Social Sciences (SPSS) version 11.5 for Windows (2002) using F test. In addition to F test, Odds ratio was calculated according to the formula given by Schlesselman (1982). 


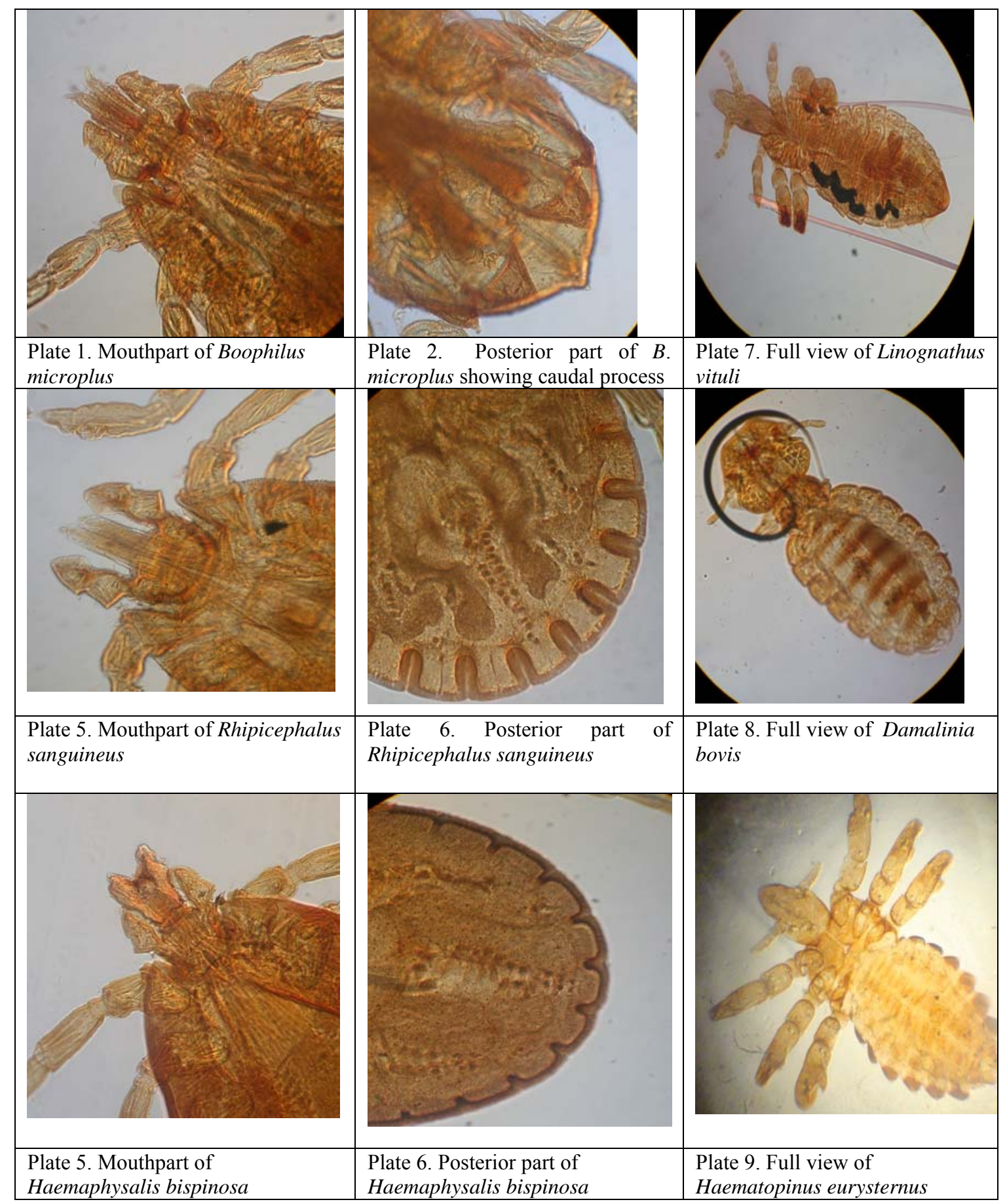




\section{S. A. Rony and others}

\section{RESULTS AND DISCUSSION \\ Overall prevalence}

Of 206 cattle examined, $132(64.07 \%)$ were found infested with one or more species of ticks (Table 1). The findings of this study agree with the reports of Islam et al. (2009) in Sirajganj, Kamal et al. (1996) in Chittagong of Bangladesh, who recorded $65.5 \%$ and $65.4 \%$ prevalence of ectoparasites in cattle, respectively. The findings of this study differ with the previous findings of some other scientists. Higher prevalence $(75.1 \%)$ in cattle was reported by Sajid et al. (2008) in Pakistan. Roy et al. (2001) reported 36.31\% prevalence of tick infestation in cattle at Madhupur in Bangladesh.

Table 1. Overall prevalence of ectoparasites in cattle $(\mathrm{N}=206)$

\begin{tabular}{|lcccc|}
\hline Species of ectoparasite involved & $\begin{array}{c}\text { No of animal } \\
\text { affected }\end{array}$ & $\begin{array}{c}\text { Prevalence } \\
(\%)\end{array}$ & Range & Mean \pm SE \\
\cline { 3 - 5 } & 94 & 45.63 & $1-7$ & $2.64 \pm 0.12$ \\
Boophilus microplus & 34 & 16.50 & $1-2$ & $1.09 \pm 0.04$ \\
Rhipicephalus sanguineus & 76 & 36.89 & $1-4$ & $1.68 \pm 0.09$ \\
Linognathus vituli & 48 & 23.30 & $1-3$ & $1.38 \pm 0.09$ \\
Haematopinus eurysternus & 37 & 17.96 & $1-2$ & $1.05 \pm 0.03$ \\
Damalinia bovis & 17 & 8.25 & $1-2$ & $1.12 \pm 0.08$ \\
Total & 132 & 64.07 & $1-7$ & $1.49 \pm 0.80$ \\
\hline
\end{tabular}

*Total number of animals affected is less than the summation of individual infestation because same animal was infested by more than one type of ectoparasites. $\mathrm{N}=$ Total animal examined.

Three species of arachnids namely, Boophilus microplus (45.63\%), Rhipicephalus sanguineus (16.50\%) and Haemaphysalis bispinosa (16.50\%) and 3 species of lice namely, Linognathus vituli (23.30\%), Haematopinus eurysternus $(17.96 \%)$ and Damalinia bovis $(8.25 \%)$ were identified. This is similar to the findings of Islam et al. (2006) who reported B. microplus $(42.4 \%) H$. bispinosa $(12.0 \%)$ and $R$. sanguineus $(10.8 \%)$ in cattle in Bangladesh. Razzak and Shaikh (1969) recorded 33.4\% cattle infested with ticks such as Boophilus microplus, Haemaphysalis bispinosa and Hyalomma sp. The differences between the results of present and earlier study might be due to variation in the geographical locations, climatic conditions of the experimental area, methods of study, selection of sampling animal and breed of animal studied.

\section{Age-wise prevalence}

It was observed that, prevalence of ectoparasites was significantly $(p<0.05)$ higher in older animals aged $>8$ year $(71.11 \%)$ followed by in adult aged $>2$ years- 8 years $(65.45 \%)$ and lowest in young aged $<2$ year (47.05\%) (Table 2). The mean tick burden was higher in case of adult (1.87 \pm 0.154$)$ followed by in old $(1.54 \pm 0.124)$ and in young (1.40 \pm 0.234$)$. The results of present study agree with Islam et al. (2009) who found that prevalence of ectoparasitic infestation was higher in old cattle $(61.5 \%)$ followed by calves $(56 \%)$ and adult (38.5\%) and calves had 2.0 times and 1.26 times more susceptibility to ectoparasitic infestation than the adults and older animals. On the other hand, Stuti et al. (2007) reported that, calves (below one year) were the most susceptible (65.38\%) followed by grownups (34.60\%) and adults (14.91\%) cattle.

Manan et al. (2007) found that resistance in the animals was building up as the age advances and the animals became more adoptable than in younger state irrespective of the farm species. It is hypothesized that the strong innate immunity and age resistance of young cattle are responsible for their less vulnerability to tick infestation (Sarkar, 2007) and in such way, leads to less ectoparasitic burden.

\section{Seasonal prevalence}

Prevalence of ectoparasites was higher in summer season (78.46\%) followed by winter (62.85\%) and lowest in rainy season $(33.3 \%)$. In summer, cattle were 3.35 and 2.15 times more susceptible to such parasitism than rainy and winter season, respectively (Table2). 
Table 2. Prevalence of ectoparasites in Cattle of Bhawal forest based on age of animal and seasons of study conducted

\begin{tabular}{|c|c|c|c|c|c|c|}
\hline \multirow[t]{2}{*}{ Species of ectoparasites } & \multicolumn{3}{|c|}{ Age of the cattle } & \multicolumn{3}{|c|}{ Seasons } \\
\hline & $\begin{array}{l}\text { Young* } \\
\text { No. }(\%)\end{array}$ & $\begin{array}{l}\text { Adult* } \\
\text { No. }(\%)\end{array}$ & \begin{tabular}{|l|} 
Old* \\
No. $(\%)$
\end{tabular} & $\begin{array}{l}\text { Summer* } \\
\text { No. }(\%)\end{array}$ & $\begin{array}{l}\text { Rainy* } \\
\text { No. (\%) }\end{array}$ & $\begin{array}{l}\text { Winter* } \\
\text { No. }(\%)\end{array}$ \\
\hline Boophilus microplus & $18(35.29)$ & $51(46.36 \%)$ & $25(55.55 \%)$ & $39(60.0 \%)$ & $23(32.39 \%)$ & $32(45.71 \%)$ \\
\hline Haemaphysalis bispinosa & $6(11.76)$ & $19(17.27 \%)$ & $9(20.0 \%)$ & $15(23.07 \%)$ & $10(14.08 \%)$ & $9(12.85 \%)$ \\
\hline Rhipicephalus sanguineus & $12(23.52)$ & $45(40.91 \%)$ & $19(42.22 \%)$ & $28(43.07 \%)$ & $17(23.94 \%)$ & $31(44.28 \%)$ \\
\hline Linognathus vituli & $11(21.57)$ & $29(26.36 \%)$ & $8(17.77 \%)$ & $18(27.69 \%)$ & $8(11.26 \%)$ & $22(31.43 \%)$ \\
\hline Haematopinus eurysternus & $3(5.88)$ & $18(16.36 \%)$ & $16(35.56 \%)$ & $7(10.77 \%)$ & $15(21.13 \%)$ & $15(21.43 \%)$ \\
\hline Damalinia bovis & $4(7.84)$ & $10(9.09 \%)$ & $3(6.67 \%)$ & $2(3.07 \%)$ & $6(8.45 \%)$ & $9(12.86 \%)$ \\
\hline Overall Prevalence & $28(54.90)$ & $72(65.45 \%)$ & $32(71.11 \%)$ & $51(78.46 \%)$ & $37(52.11 \%)$ & $44(62.85 \%)$ \\
\hline \multirow{3}{*}{ Odds Ratio } & \multicolumn{3}{|c|}{ Adult vs Young $=1.56$} & \multicolumn{3}{|c|}{ Summer Vs Rainy $=3.35$} \\
\hline & \multicolumn{3}{|c|}{ Old vs Adult $=1.29$} & \multicolumn{3}{|c|}{ Winter Vs Rainy $=1.55$} \\
\hline & \multicolumn{3}{|c|}{ Old vs Young $=2.02$} & \multicolumn{3}{|c|}{ Summer Vs Winter $=2.15$} \\
\hline Level of significance & \multicolumn{3}{|c|}{$P$ value $=0.028$} & \multicolumn{3}{|c|}{$P$ value $=0.002$} \\
\hline
\end{tabular}

*Summer: March- June; Rainy: July-October and Winter: November-February.

* Young ( $\leq 2$ years); Adult ( $>2$ years to 8 years) and old ( $>8$ years).

In contrast, Salih et al. (2008) found the highest number of ticks occur during the rainy season. Sanjay et al. (2007) reported the seasonal prevalence of tick infestation significantly more during the rainy $(24.33 \%)$ and summer seasons $(21.58 \%)$ as compared to the winter season $(4.03 \%)$. He also reported lice infestation significantly higher in winter $(25.89 \%)$ than in the rainy $(2.48 \%)$ and summer seasons $(8.93 \%)$. Biu and Nwosu (1998) found that although most of the ticks occurred in relatively low numbers throughout the year, they were generally most common from the second half of the rainy season through the dry season. On the contrary, Stuti et al. (2007) observed low activity of B. microplus in very dry and very cold temperatures at farm level.

The rise of infestation in summer may be due to rise of temperature in late winter leading to gradual increase in the load as well as percentage of infestation in May and June (Roy et al. 2001). The contrast in between the present and earlier findings can be explained by the fact of variation of geographical location of experimental area, topography, the composition of soil type and humidity, lack of control group of population and most importantly, the changed climatic condition of the earth.

\section{Sex related prevalence}

It was observed that the prevalence of ectoparasitic infestation was significantly $(p<0.05)$ higher in female $(69.74 \%)$ than the male $(41.17 \%)$ cattle (Table 3$)$. The mean tick burden was higher in female $(1.54 \pm 0.896)$ than in male (1.43 \pm 0.136$)$. It was also observed that $74.78 \%$ of cattle with poor nutritional condition were affected with ectoparasitic infestation. This result agree with the report of Sarkar (2007) who reported the prevalence of ectoparasites were significantly $(p<0.01)$ higher in female than male.

\section{Nutritional factor related prevalence}

Cattle under poor nutritional level were 2.88 times more vulnerable to ectoparasitic infestation than animals with normal health $(51.57 \%)$ (Table 3$)$. The mean tick burden was higher in exhausted cattle $(1.52 \pm 0.10)$ than in cattle with normal health (1.48 \pm 0.14$)$.

The present study agrees with the earlier study of Lapage (1962) who found malnourished animals are more susceptible to any infection as they are immune compromised. Moreover, Etter et al. (1999) also found that in immune compromised animals, prevalence of tick is usually increased.

\section{Rearing system related prevalence}

The present study implied that $69.06 \%$ of cattle brought up under free-range system were affected with ectoparasitic infestation (Table 3). Such animals were 2.46 times more vulnerable to ectoparasitic infestation than cattle reared intensively (38.89\%). It is similar to the finding of Rabbi (2006) who reported, the highest ectoparasitic infestation in semi-intensive system (59.7\%) followed by extensive system (33.5\%) and intensive system $(8.27 \%)$. 


\section{S. A. Rony and others}

The impact of ticks and tick borne diseases on the individual and national economics warrants application of appropriate tick control strategies on priority basis (Bansal, 2005). Various studies have shown that acaricidetreated and/ or tick free animals produce better than tick infested animals (Sajid et al., 2007).

Table 3. Prevalence of ectoparasites in Cattle of Bhawal forest based on sex, health status and rearing systems of animals studied

\begin{tabular}{|c|c|c|c|c|c|c|}
\hline \multirow[t]{3}{*}{ Species of ectoparasites } & \multicolumn{2}{|c|}{ Sex } & \multicolumn{2}{|c|}{ Health status } & \multicolumn{2}{|c|}{ Rearing systems } \\
\hline & Male & Female & Normal & Poor & Free-range & Semi-intensive \\
\hline & No. $(\%)$ & No. $(\%)$ & No. $(\%)$ & No. $(\%)$ & No. $(\%)$ & No. $(\%)$ \\
\hline Boophilus microplus & $37(42.52 \%)$ & $57(47.89 \%)$ & $33(34.79 \%)$ & $61(54.95 \%)$ & $90(49.72 \%)$ & $4(22.22 \%)$ \\
\hline Haemaphysalis bispinosa & $11(12.64 \%)$ & $23(19.32 \%)$ & $11(11.57 \%)$ & $23(20.72 \%)$ & $34(18.78 \%)$ & $0(0.0 \%)$ \\
\hline Rhipicephalus sanguineus & $28(32.18 \%)$ & $48(40.34 \%)$ & $27(28.42 \%)$ & $49(44.14 \%)$ & $74(40.88 \%)$ & $2(11.11 \%)$ \\
\hline Linognathus vituli & $13(14.94 \%)$ & $35(29.41 \%)$ & $18(18.94 \%)$ & $30(27.02 \%)$ & $46(25.41 \%)$ & $2(11.11 \%)$ \\
\hline Haematopinus eurysternus & $14(16.09 \%)$ & $23(19.32 \%)$ & $7(7.36 \%)$ & $30(27.02 \%)$ & $37(20.44 \%)$ & $0(0.0 \%)$ \\
\hline Damalinia bovis & $4(4.59 \%)$ & $13(10.92 \%)$ & $4(4.21 \%)$ & $13(11.71 \%)$ & $17(9.39 \%)$ & $0(0.0 \%)$ \\
\hline Overall Prevalence & $49(41.17 \%)$ & $83(69.74 \%)$ & $49(51.57 \%)$ & $83(74.78 \%)$ & $125(69.06 \%)$ & $7(38.89 \%)$ \\
\hline Odds Ratio & \multicolumn{2}{|c|}{ Female Vs Male $=1.78$} & \multicolumn{2}{|c|}{ Poor Vs Normal $=2.88$} & \multicolumn{2}{|c|}{$\begin{array}{l}\text { Free-range Vs Semi-intensive }= \\
2.46\end{array}$} \\
\hline Level of significance & \multicolumn{2}{|c|}{$P$ value $=0.014$} & \multicolumn{2}{|c|}{$P$ value $=0.007$} & \multicolumn{2}{|c|}{$P$ value $=0.001$} \\
\hline
\end{tabular}

\section{REFERENCES}

1. Ashraful Alam (2008). Protect Bhawal Sal Forest, The Daily Star dated on 5 April, 2008.

2. Bansal, G. C. (2005). Bovine theileriosis in India: an overview. Proceedings of National Academy of Science, India, 75:134-43.

3. BBS (Bangladesh Bureau of Statistics). (2008). Statistical Pocketbook of Bangladesh, Statistics Division, Ministry of Planning, Government of the People of Republic of Bangladesh, Dhaka, pp: 256.

4. Biu AA and Nwosu CO (1998). Seasonal prevalence of cattle ticks in Maiduguri, Borno State. Entomology in the Nigerian economy Research focus in the 21st century, pp.133-139.

5. Branscheid. W and Schroer (1997). Damage to cattle hides, detection, frequency and economic importance. Fleischwirtschaft. 77: 333-37.

6. Cable RM (1967). An Illustrated Laboratory Manual of Parasitology, $4^{\text {th }}$ edition, Burgress Publishing Co., Minneapolis, Minnesota, USA. p. 111-131.

7. Etter E, Chartier C, Lefrileux Y and Borgid LP (1999). The influence of nutrition on the periparturient rise in fecal egg counts in dairy goats. Revue de Medicine Veterinaire, 150:975-980.

8. Hourrigan JL (1979). Spread and detection of Psoroptic scabies of cattle in the United States, Journal of American Veterinary Association. 175:1278-1280.

9. Islam MK, Alim MA, Tsuji N and Mondal MMH (2006). An investigation into the distribution, host-preference and population density of Ixodid ticks affecting domestic animals in Bangladesh. Tropical Animal Health and Production, 38: 485-490.

10. Islam MS, Rahman SA, Sarker P, Anisuzzaman and Mondal MMH (2009). Prevalence and population density of ectoparasitic infestation in cattle in Sirajgonj district, Bangladesh. Bangladesh Research Publications Journal. 2(1): 332339.

11. Jongejan F and Uilenberg G (2004). The global importance of ticks, Parasitology.129:S3-S14.

12. Kamal AHM, Uddin KH, Islam MM and Mondal MMH (1996). Prevalence of economically important ticks in cattle and goat at Chittagong hilly areas of Bangladesh. Asian-Australasian Journal of Animal Sciences. Vol.9. No.5.

13. Kettle PR (1974). The influence of cattle lice, Damalinia bovis and Linognathus vituli on weight gain in beef animals. New Zealand Vet. J., 22: 10-11.

14. Lapage G (1962). Monig's Veterinary Helminthology and Entomology, $5^{\text {th }}$ edi. Bailliere, Tindall and Cox Ltd. London, UK. pp:556-723.

15. Loomis EC (1986). Ectoparasites of cattle. Vet. Clin. North America, 2: 299-321.

16. Manan A, Khan Z, Ahmad B and Abdullah (2007). Prevalence and identification of ixodid tick genera in frontier region Peshawar. Journal of Agricultural and Biological Science, 2(1): 21-25. 


\section{Epidemiology of ectoparasitic infestations in cattle}

17. Nafstad $\mathrm{O}$ and $\mathrm{H}$ Gronstol (2001b). Variation in the level of grain defect light flecks and spots on cattle hides. Acta. Vet. Scand., 42: 91- 98.

18. Nelson WA (1984). Effects of nutrition on animals on their ectoparasites. J. Med. Entomol., 21: 621-35.

19. Niyonzema A and Kiltz HH (1986). Control of ticks and tick-borne diseases in Burundi. Australian Center for International Agricultural Research. 17:16-17.

20. Norval RAI, Fivaz BH, Lawrence JA and Brown AF (1984). Epidemiology of tick-borne diseases of cattle in Zimbabwe, Tropical Animal Health and Production, 16:63-70.

21. Rabbi AKMA (2006). Parasitism in Black Bengal Goats in relation to different feeding systems. M.S. thesis. Department of Parasitology, Bangladesh Agricultural University, Mymensingh.

22. Razzak A and Shaikh H (1969). A survey on the prevalence of ticks on cattle in East Pakistan. Pakistan Journal of Veterinary Science, 3:54-60.

23. Roy AK, Rahman MH, Majumder S and Sarker AS (2001). Ecology of ticks and tick-borne blood protozoa in Madhupur Forest Area, Tangail. Bangladesh Veterinary Journal, 17:90-97.

24. Sajid MS, Iqbal I, Khan MN and Muhammad G (2008). Point prevalence of hard ticks (Ixodids) infesting domestic ruminants of Lower Punjab, Pakistan. International Journal of Agriculture and Biology. 10(3): 349-351.

25. Salih DA, Julia II, Hassan SM, El-Hussain AM and Jongejan F (2008). Preliminary Survey of ticks ( Acari: Ixodidae) on Cattle in Central Equatoria State, Southern Sudan. Onderstepoort Journal of Veterinary Research, 75 (1): 47-53.

26. Samad MA (2000). An overview of livestock research reports published during the twentieth century in Bangladesh. Bangladesh Vet J 34: 53 -149.

27. Sanjay K, Prasad KD and Deb AR (2007). Seasonal prevalence of different ectoparasites infecting cattle and buffaloes. Journal of Research, 16(1): 159-163.

28. Sarkar M (2007). Epidemiology and pathology of ectoparasitic infestation in Black Bengal Goats in Bangladesh. M.Sc. thesis. Department of Parasitology, Bangladesh Agricultural University, Mymensingh.

29. Schlesselman JJ (1982). Case Control Studies. Oxford University Press, New York, pp: 174-177.

30. Soulsby EJI (1982). Helminths, Arthropod and Protozoa of Domesticated Animals, $7^{\text {th }}$ edition. Bailliere, Tindall and Cassell Ltd. pp.136-346, 365-491 and 763-778.

31. Stuti V, Yadav CL, Kumar RR and Rajat G (2007). Seasonal Activity of Boophilus microplus on Large Ruminants at an Organised Livestock Farm. Journal of Veterinary Parasitology, 21(2): 125-128.

32. Wall R and Shearer D (1997). Veterinary Entomology, $1^{\text {st }}$ edition, Chapman and Hall. London, UK. p.265 and 290. 